\title{
Estimation of the Greenland ice sheet surface mass balance for the 20th and 21st centuries
}

\author{
X. Fettweis ${ }^{1}$, E. Hanna ${ }^{2}$, H. Gallée ${ }^{3}$, P. Huybrechts ${ }^{4}$, and M. Erpicum ${ }^{1}$ \\ ${ }^{1}$ Département de Géographie, Université de Liège, Liège, Belgium \\ ${ }^{2}$ Department of Geography, University of Sheffield, Sheffield, UK \\ ${ }^{3}$ LGGE - Laboratoire de Glaciologie et Géophysique de l'Environnement, Grenoble, France \\ ${ }^{4}$ Departement Geografie, Vrije Universiteit Brussel, Brussel, Belgium
}

Received: 6 March 2008 - Published in The Cryosphere Discuss.: 9 April 2008

Revised: 19 August 2008 - Accepted: 4 September 2008 - Published: 24 September 2008

\begin{abstract}
Results from a regional climate simulation (19702006) over the Greenland ice sheet (GrIS) reveals that more than $97 \%$ of the interannual variability of the modelled Surface Mass Balance (SMB) can be explained by the GrIS summer temperature anomaly and the GrIS annual precipitation anomaly. This multiple regression is then used to empirically estimate the GrIS SMB since 1900 from climatological time series. The projected SMB changes in the 21 st century are investigated with the set of simulations performed with atmosphere-ocean general circulation models (AOGCMs) of the Fourth Assessment Report of the Intergovernmental Panel on Climate Change (IPCC AR4). These estimates show that the high surface mass loss rates of recent years are not unprecedented in the GrIS history of the last hundred years. The minimum SMB rate seems to have occurred earlier in the 1930s and corresponds to a zero SMB rate. The AOGCMs project that the SMB rate of the 1930s would be common at the end of 2100 . The temperature would be higher than in the 1930s but the increase of accumulation in the 21 st century would partly offset the acceleration of surface melt due to the temperature increase. However, these assumptions are based on an empirical multiple regression only validated for recent/current climatic conditions, and the accuracy and time homogeneity of the data sets and AOGCM results used in these estimations constitute a large uncertainty.
\end{abstract}

\section{Introduction}

Mass balance variations of the GrIS play an important role in global sea level fluctuations and oceanic THC changes.

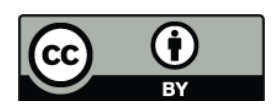

Correspondence to: X. Fettweis (xavier.fettweis@ulg.ac.be)
On the one hand, GrIS mass balance changes appear to have contributed several metres to some of the sea-level fluctuations since the last interglacial period known as the Eemian, $125 \mathrm{~K}$ yr BP (Cuffey and Marshall, 2000) and are expected to contribute to sea-level rise under the projected future global warming throughout this century (Meehl et al., 2007). On the other hand, increases in the freshwater flux from the Greenland ice sheet (run-off of the surface melt water, basal melting and glacier discharge) could perturb the THC by reducing the density contrast driving the thermohaline circulation (Rahmstorf et al., 2005). Any weakening of the THC in response to a surface warming and an increasing freshwater flux induced by global warming (Gregory et al., 2005; Swingedouw et al., 2006) would reduce the heat input to the North Atlantic ocean and subsequently reduce the warming in regions including Europe. The IPCC 4th Assessment Report (IPCC AR4) projected that the Greenland ice sheet is likely to lose mass because the increasing run-off is expected to exceed the precipitation increase in a warmer climate but did not expand on the individual model estimates or mass balance components (Meehl et al., 2007).

In this study, we provide estimates of the GrIS SMB from 1900 to 2100 based on a multiple regression model using anomalies of GrIS summer temperature (from 1 June to 31 August) and from GrIS annual precipitation. A 37-yr (19702006) simulation of the GrIS performed by the regional climate model MAR (Modèle Atmosphérique Régional) shows that $97 \%$ of the interannual variability of the modelled SMB is explained by these anomalies (Fettweis, 2007). Such a strong correlation is also confirmed by the model of Hanna et al. (2008) driven by the ECMWF (re)analysis. We use this relation to empirically estimate the GrIS SMB since 1900 until now from climatological time series and analyses. The 21 st century is investigated with results from the AOGCMs used in the IPCC AR4 (Randall et al., 2007). Section 2 explains in detail both the method and data used. Estimates of

Published by Copernicus Publications on behalf of the European Geosciences Union. 


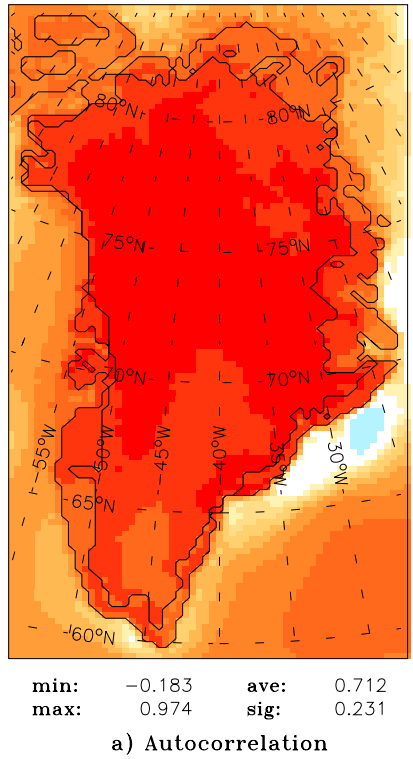

of the JJA $3 \mathrm{~m}$-Temperature

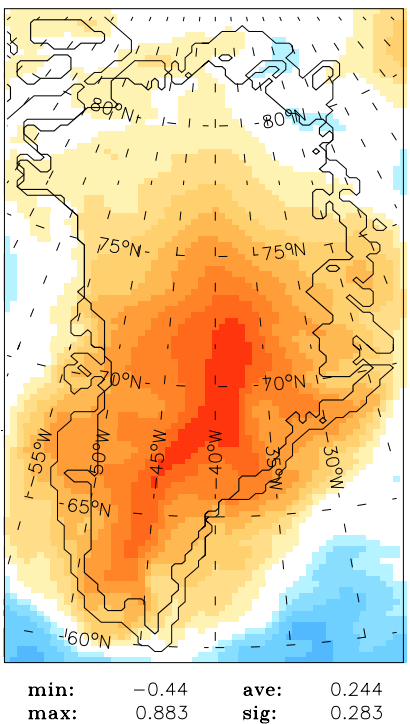

b) Autocorrelation of the annual precipitation

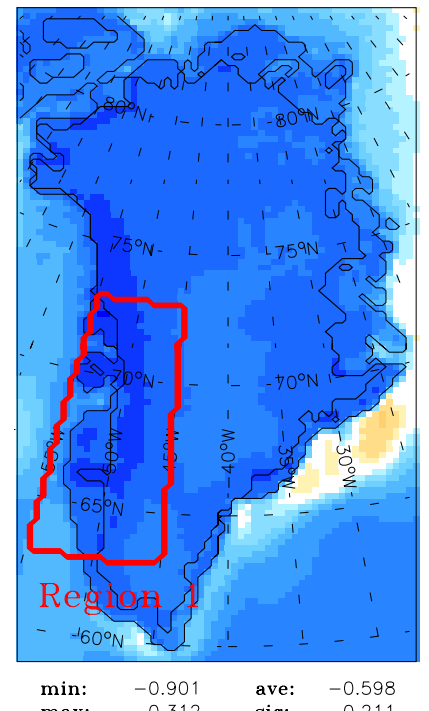

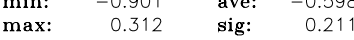

c) Correlation between the JJA 3m-Temp. and the GrIS SMB

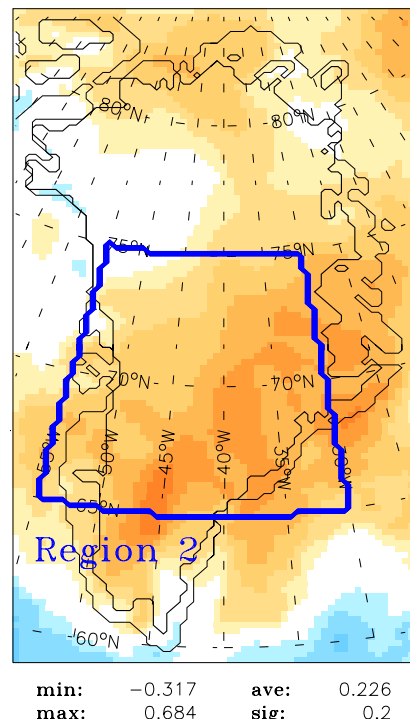

d) Correlation between the annual precip. and the GrIS SMB

Fig. 1. Left: spatial autocorrelation of the (a) JJA 3 m-temperature and (b) annual precipitation simulated by MAR over the period 19701999. The spatial autocorrelation is defined as the correlation between time series of the average ice-sheet summer temperature and annual total ice-sheet precipitation with the respective temperature/precipitation values for each grid point. Right: the correlation between the time series of the MAR-simulated GrIS SMB and (c) JJA 3 m-temperature and (d) annual precipitation at each grid location. Minimum and maximum values are indicated as well as the ice sheet average and the standard deviation. Finally, this figure shows the regions quoted in the text. Region 1: $55^{\circ} \mathrm{W} \leq$ longitude $\leq 45^{\circ} \mathrm{W}$ and $63^{\circ} \mathrm{N} \leq$ latitude $\leq 73^{\circ} \mathrm{N}$. Region 2 : $55^{\circ} \mathrm{W} \leq$ longitude $\leq 30^{\circ} \mathrm{W}$ and $65^{\circ} \mathrm{N} \leq$ latitude $\leq 75^{\circ} \mathrm{N}$.

near past and future GrIS SMB rates are presented in Sect. 3 and Sect. 4, respectively. Section 5 contains a discussion of the results.

\section{Method}

To a first approximation, the GrIS SMB variability $\left(\triangle \mathrm{SMB}_{\mathrm{GrIS}}\right)$ is driven by the GrIS annual precipitation anomaly $\left(\Delta P_{\mathrm{yr}}\right)$ minus the GrIS meltwater run-off rate variability. According to Box et al. (2004) and Fettweis (2007), the run-off rate variability can be approximated by the GrIS summer (from 1 June to 31 August) $3 \mathrm{~m}$-temperature $\left(\Delta T_{\mathrm{jja}}\right)$ to give this multiple regression:

$\Delta \mathrm{SMB}_{\mathrm{GrIS}} \simeq a \Delta T_{\mathrm{jja}}+b \Delta P_{\mathrm{yr}}$

where $a$ and $b$ are constant parameters. These parameters are determined by solving the multiple regression equation using the simulated GrIS SMB anomaly time series and both JJA temperature and annual precipitation anomaly time series.

By using de-trended results simulated by MAR, a correlation coefficient of 0.97 is obtained between the simulated and estimated GrIS SMB anomaly from Eq. (1) over the period 1970-1999. The root mean square error (RMSE) represents $25 \%$ of the GrIS SMB anomaly standard deviation. Such a correlation motivated us to use this equation to extend the estimate of the SMB variability with the help of climatological time series and the outputs from analyses and the AOGCMs used in the IPCC AR4. The 30-yr reference period (19701999) is chosen because it covers most of the available data sets and model results used in this study.

Figure 1 shows where the regional variability of the MAR $3 \mathrm{~m}$-temperature and precipitation best captures the variability of the MAR SMB of the GrIS. With the aim of applying this multiple regression to other data sets (at low resolution and without an ice sheet/land mask), we delimited regions in latitude/longitude on the GrIS where the variability of precipitation and temperature will be captured to estimate the SMB following Eq. (1). These regions (called Region 1 and Region 2 hereafter) are different for temperature and precipitation, and are plotted in Figs. 1 and 2. The west coast of the GrIS was chosen to take the temperature anomalies (Region 1) because the correlation with the SMB time series is the highest (see Fig. 1 and 2) in this region. Furthermore, there are a lot of Danish Meteorological Institute (DMI) weather stations along the west coast on which the datasets (CRU, GHCN,...) are based. The Region 2 for precipitation anomaly is centred on the Summit where the spatial autocorrelation is the highest. The boundaries of these regions are chosen to have higher correlations between the GrIS SMB modelled by MAR and the SMB estimated by temperature/precipitation anomalies simulated by MAR model (following Fig. 1) as well as anomalies from all 
Table 1. Five climatological data sets used in this paper to estimate the GrIS SMB.

\begin{tabular}{|c|c|c|c|c|c|}
\hline Abbreviation & Name & Period & Resolution & Web site & Reference \\
\hline CRU & Climate Research Unit TS 2.1 & 1901-2002 & $0.5^{\circ}$ & http://www.cru.uea.ac.uk & Mitchell and Jones (2005) \\
\hline ECMWF & ECMWF (Re)-Analysis & 1958-2006 & $1.125^{\circ}$ & http://www.ecmwf.int & Uppala et al. (2005) \\
\hline GHCN & Global Histo. Climato. Network 2 & 1900-2006 & $5^{\circ}$ & http://lwf.ncdc.noaa.gov/ & Peterson and Vose (1997) \\
\hline NCEP & NCEP/NCAR Reanalysis 1 & 1948-2006 & $\sim 2^{\circ}$ & http://www.cdc.noaa.gov/cdc/data.ncep.reanalysis.html & Kalnay et al. (1996) \\
\hline UDEL & Arctic Land-Surface TS 1.01 & 1930-2000 & $0.5^{\circ}$ & http://climate.geog.udel.edu/ climate/html_pages/download.html\#ac_temp_ts2 & \\
\hline
\end{tabular}

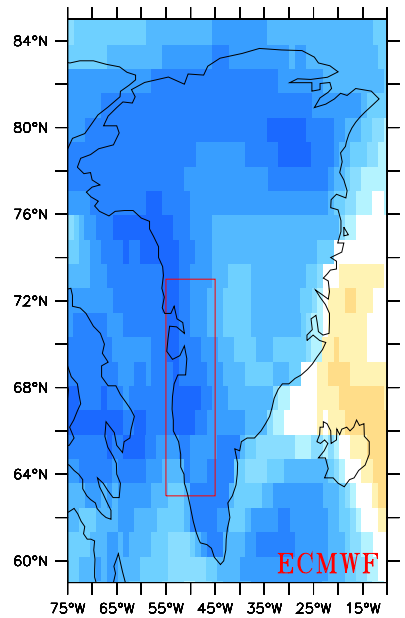

Temp. and MAR SMB correlation

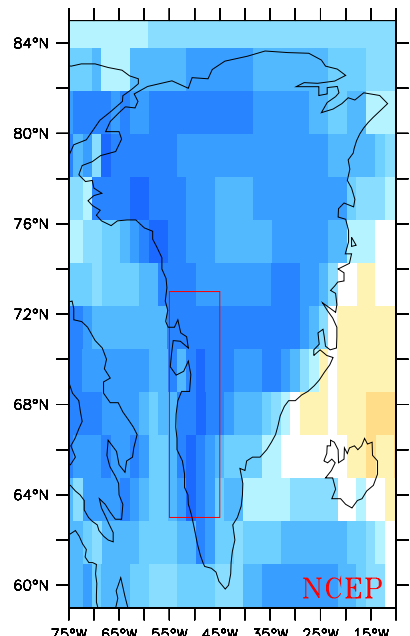

(5)
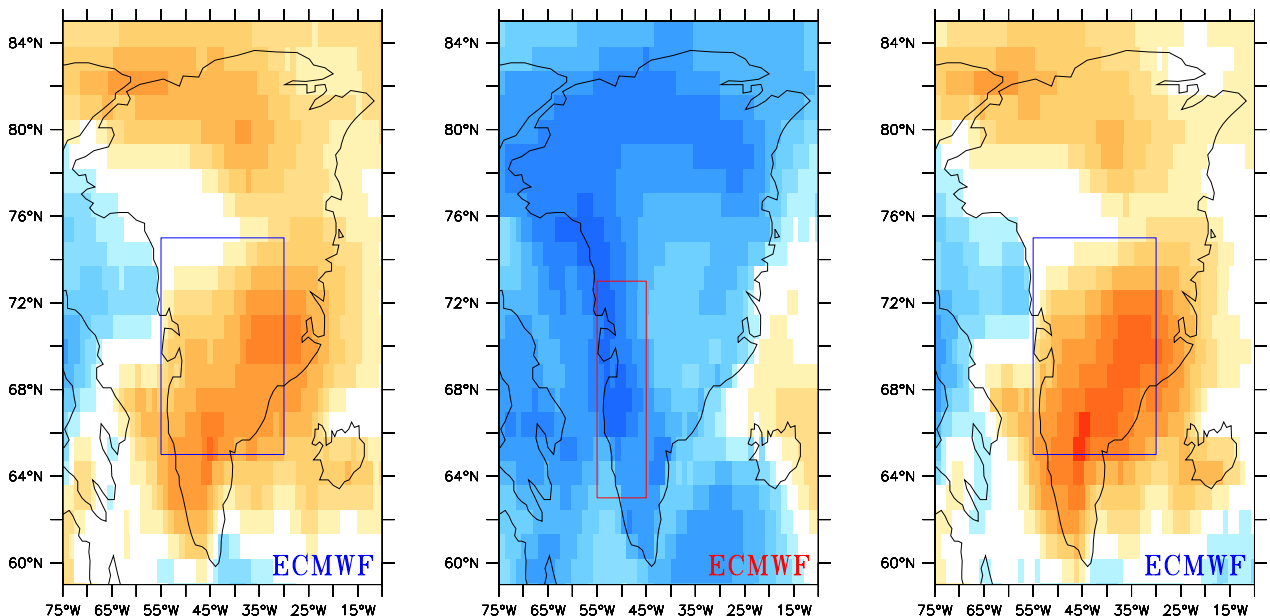

Precip. and MAR SMB correlation
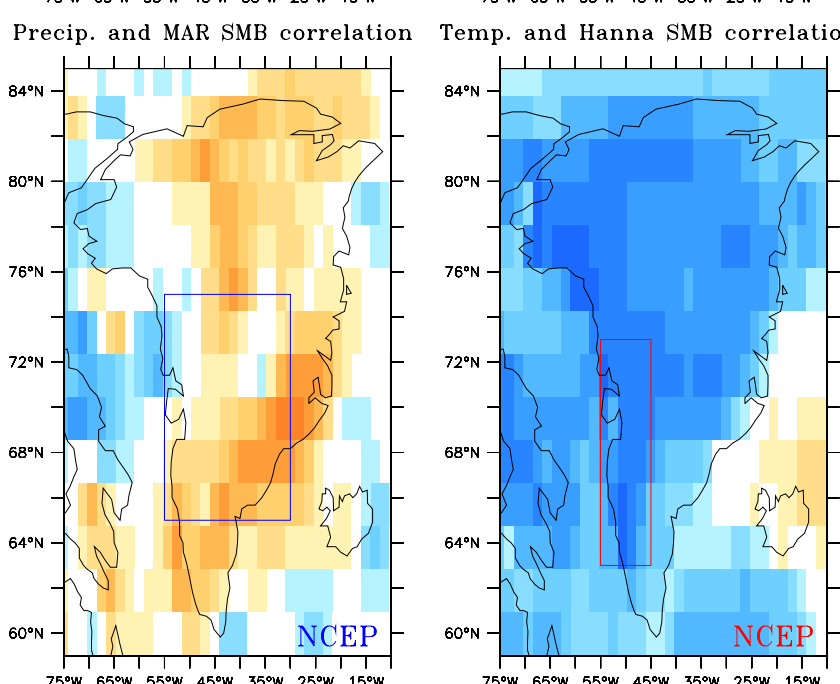

ecip. and Hanna SMB correlation

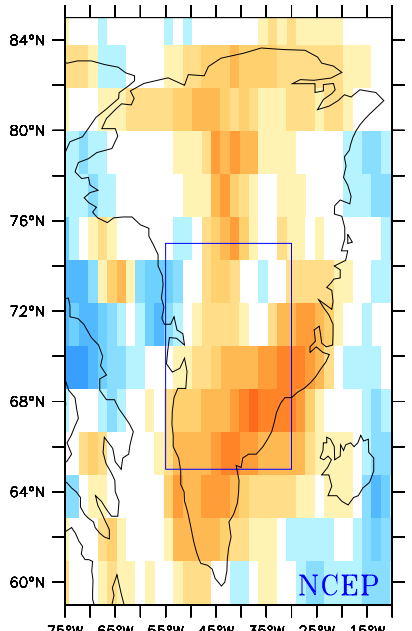

Precip. and MAR SMB correlation Temp. and Hanna SMB correlation Precip. and Hanna SMB correlation

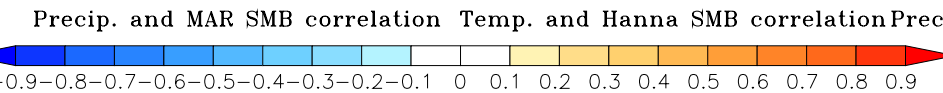

Fig. 2. Correlation between the time series of the MAR (resp. Hanna08) simulated GrIS SMB and the summer 3 m-temperature and annual precipitation from the ECMWF (resp. NCEP/NCAR) reanalysis at each grid location over 1970-1999. 
Table 2. Correlation coefficient between the de-trended annual temperature (resp. precipitation) anomaly averaged over Region 1 (resp. Region 2) from the different data sets and simulated by the MAR model over the reference period (1970-1999). The correlation coefficient as well as the RMSE (in $\mathrm{km}^{3}$ ) between the de-trended GrIS SMB modelled by MAR and the SMB estimated by temperature/precipitation de-trended anomaly time series are also shown. Finally, the parameters $a$ and $b$ (computed by using de-trended normalized time series) are listed as well as their ratio and the standard error of these paramaters.

\begin{tabular}{lccccccc}
\hline Name & $\Delta T$ corr. & $\Delta P$ corr. & $\Delta$ SMB corr. & RMSE & $a$ & $b$ & $k=a / b$ \\
\hline CRU & 0.79 & 0.84 & 0.81 & 64.6 & $-66.6 \pm 13$ & $49.4 \pm 13$ & $-1.35(-2.16,-0.87)$ \\
ECMWF & 0.92 & 0.94 & 0.89 & 49.2 & $-65.1 \pm 10$ & $62.6 \pm 10$ & $-1.04(-1.42,-0.77)$ \\
GHCN & 0.83 & 0.82 & 0.83 & 61.4 & $-61.8 \pm 12$ & $53.2 \pm 12$ & $-1.16(-1.82,-0.75)$ \\
NCEP & 0.91 & 0.90 & 0.89 & 49.6 & $-75.1 \pm 10$ & $61.4 \pm 10$ & $-1.22(-1.62,-0.92)$ \\
UDEL & 0.86 & 0.80 & 0.83 & 61.0 & $-73.7 \pm 12$ & $47.7 \pm 12$ & $-1.65(-2.61,-1.09)$ \\
MAR & 1.0 & 1.0 & 0.97 & 28.5 & $-63.3 \pm 6$ & $64.8 \pm 6$ & $-0.98(-1.18,-0.81)$ \\
\hline
\end{tabular}

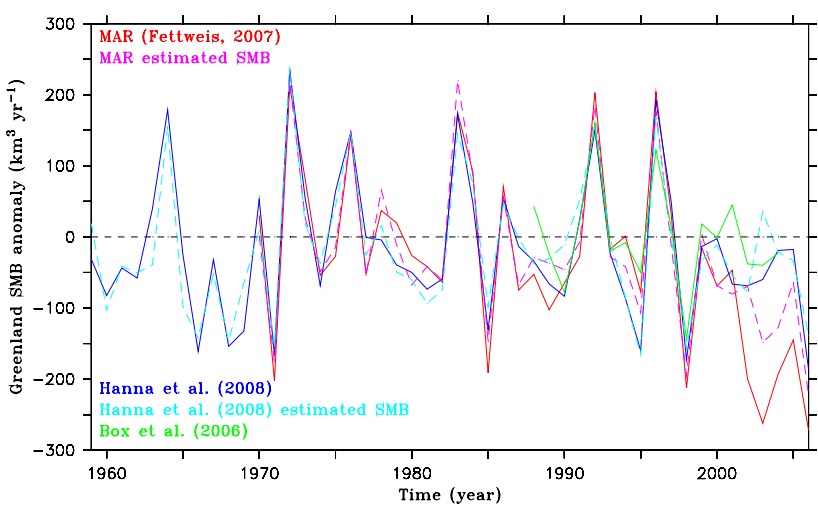

Fig. 3. The GrIS SMB anomaly simulated by the MAR model and estimated with Eq. (1) by using temperature/precipitation anomalies simulated by MAR, derived using a positive degree-day and run-off/retention model based on ECMWF reanalysis Hanna et al. (2008) and estimated by using temperature/precipitation anomaly from the ECMWF (re)analysis, and simulated by the Polar MM5 model Box et al. (2006). The reference period is 1970-1999 and the temperature and precipitation anomaly are taken from Region 1 and 2 described in Fig. 1.

data sets used hereafter (see Table 2), while the choice of the boundaries of these regions does not significantly impact the results. Both regions chosen are therefore the same for all data sets.

A good agreement between the modelling from MAR and from Hanna et al. (2008) (called Hanna08 hereafter) and the estimates of the GrIS SMB anomaly by using temperature (respectively precipitation) anomaly on Region 1 (resp. 2) can be seen in Fig. 3. This figure also compares the GrIS SMB simulated by the Polar MM5 model (Box et al., 2006). The differences between these three models are briefly described in Fettweis (2007). The interannual variability compares well between the models before 2000 while this last one is higher in the MAR model than in the Hanna08 time series. The Hanna08 run-off model is forced by monthly mean atmospheric fields from the ECMWF (re)analysis which could underestimate the impact of extreme warm events during the summer and then reduce the interannual variability. After 2001, large discrepancies however occur between the models. First, in the 2000 s, there is a succession of negative SMB anomalies inducing an acceleration of the melt the following year due to the albedo feedback and the humidification of the snowpack. These feedbacks could be overestimated in the MAR model compared with other models. In addition, these feedbacks are not taken into account in the (Polar) MM5 model because the surface model is reinitialized every day in MM5. Secondly, different sensitivities of the various SMB models to several profound changes in the ECMWF model configuration/resolution used to produce ECMWF operational analyses after 2002 (as opposed to the fixed model scheme of ERA-40 (Uppala et al., 2005) for the period 1958-2001) could explain the differences in the models since 2002. The disagreement in the 2000s explains why we did not extend the 30-yr reference period (1970-1999) to the 2000s.

Finally, Oerlemans et al. (2005) use a similar estimation of Eq. (1) which is in total agreement with that we have found in Eq. (1) by using the MAR simulated time series. Using the same units as Oerlemans et al. (2005), we obtain a coefficient $a$ of $-43.3 \mathrm{~mm} / \mathrm{K}$ compared with -49 in Oerlemans et al. (2005) and a coefficient $b$ of $3 \mathrm{~mm} / \%$ compared with 3.8 in Oerlemans et al. (2005). If we use the SMB time series from Hanna08 and the temperature and precipitation anomalies time series in Region 1 and 2 from the ERA-40 reanalysis in Eq. (1) a coefficient $a$ (resp. $b$ ) of $-49.4 \mathrm{~mm} / \mathrm{K}$ (resp. $3.4 \mathrm{~mm} / \%$ ) is found, which fully agrees with those found by Oerlemans et al. (2005). These values are also in agreement with Box et al. (2006).

\section{Surface mass balance in the 20th century}

For each data set listed in Table 1, we computed the parameters $a$ and $b$ over the reference period (1970-1999) by using the GrIS SMB anomaly time series simulated by MAR and by Hanna08 in the left part of Eq. (1) and the 
Table 3. The same as Table 2 but by using results simulated by Hanna08 in the left part of Eq. (1).

\begin{tabular}{lccccc}
\hline Name & $\Delta$ SMB corr. & RMSE & $a$ & $b$ & $k=a / b$ \\
\hline CRU & 0.86 & 52.3 & $-56.8 \pm 10$ & $57.8 \pm 10$ & $-0.98(-1.41,-0.68)$ \\
ECMWF & 0.97 & 26.1 & $-55.5 \pm 5$ & $71.1 \pm 5$ & $-0.77(-0.91,-0.65)$ \\
GHCN & 0.86 & 52.5 & $-50.3 \pm 11$ & $59.7 \pm 11$ & $-0.84(-1.24,-0.57)$ \\
NCEP & 0.96 & 29.9 & $-67.0 \pm 6$ & $71.2 \pm 6$ & $-0.94(-1.11,-0.8)$ \\
UDEL & 0.86 & 52.2 & $-62.3 \pm 10$ & $53.1 \pm 10$ & $-1.17(-1.69,-0.82)$ \\
\hline
\end{tabular}
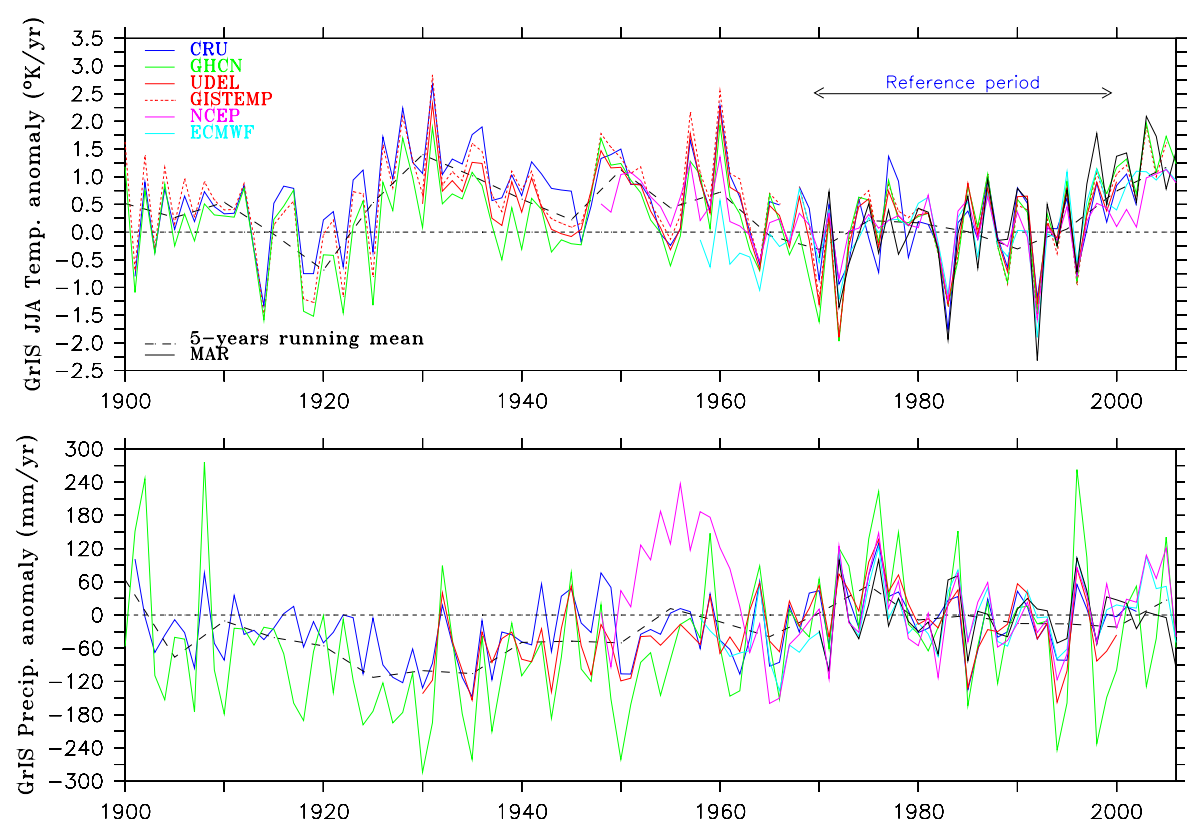

Fig. 4. Time series of the GrIS temperature (resp. precipitation) anomaly computed for Region 1 (resp. 2) from the different data sets listed in Table 1. In red dashed, the time series from GISTEMP (available at http://data.giss.nasa.gov/). Anomalies are with respect to 1970-1999. The 5-yr running mean of the averaged anomalies of the available data sets is shown in dashed black.

temperature/precipitation anomaly time series from the data set averaged on Region 1/Region 2 in the right part. The high correlation coefficient $(>0.8)$ between the GrIS SMB anomaly simulated by MAR (resp. Hanna08) and the one estimated by the data sets following Eq. (1) over 1970-1999 (see Tables 2 and 3) motivated us to extend empirically the SMB anomaly estimation to the whole period covered by the data sets by using the same previously determined parameters $a$ and $b$. These parameters are computed over 19701999 by using de-trended (i.e. with a zero trend) time series to minimise the dependence on the reference period and are applied after that to the whole time series (without correction of the trend). The anomalies refer then to the period 1970 1999. In addition, the use of de-trended time series of anomalies to compute the parameters $a$ and $b$ rather than time series of values provides a better homogeneity between the different data sets and the MAR (resp. Hanna08) model. Before continuing, it should be noted that these data set-based SMB anomaly estimates should be considered with caution.
- Firstly, these estimates are based on Eq. (1) which does not fully explain the SMB variability and uses results from the MAR and Hanna08 models (not direct observations) for the calibration.

- Secondly, by using constant parameters $a$ and $b$ through the whole period covered by the climatic dataset, we assume that the dependence of the SMB on the temperature/precipitation anomaly are the same as during 1970-1999. That is why we chose to use de-trended time series to minimise this impact.

- In addition, we assume that the data set is homogeneous through the whole period, which is not guaranteed as, for example, in the ECMWF time series after 2002.

- We assume also that the variability in Region 1 and 2 remains representative for the whole ice sheet for the entire period. Furthermore, we implicitly assume that the same mechanisms that are responsible for the interannual variability can be extended to the long term 

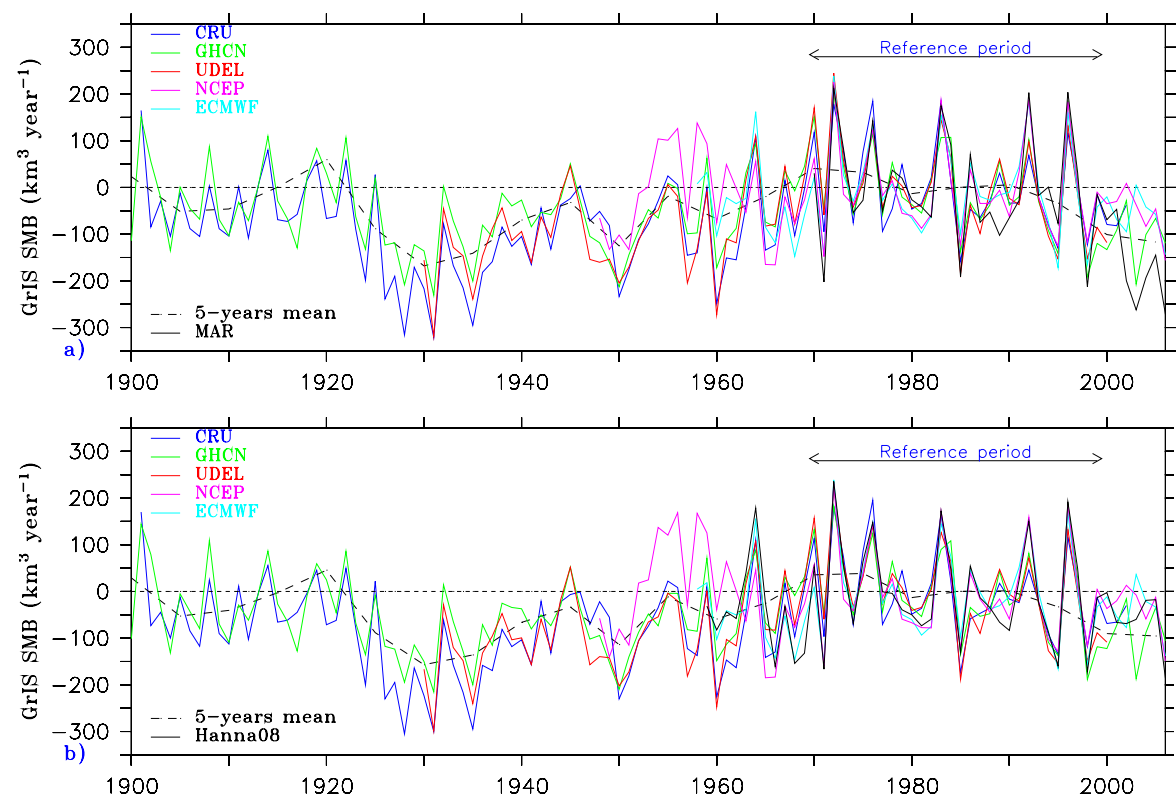

Fig. 5. (a) Time series of the estimated GrIS SMB anomaly using the SMB variability simulated by MAR (to determine the parameters $a$ and $b$ in Eq. (1)) and anomalies from the different data sets listed in Table 1 since 1900 until 2006. The reference period is 1970-1999 over which the GrIS SMB simulated by MAR and by Hanna08 is around $350 \mathrm{~km}^{3} \mathrm{yr}^{-1}$. The 5 -yr running mean of the ensemble mean is shown in dashed black. (b) The same as (a) but using the Hanna08 results to determine the parameters $a$ and $b$ in Eq. (1).

and decadal variability (for the future projections). In addition, we assume by using a linear equation that a doubling in, for instance, the temperature deviation will result in a doubling of the melt anomaly.

- Finally, there are not many in-situ observations (on which the data sets are based) available over Greenland. Such data are collected along the coast by the Danish Meteorological Institute (DMI) weather stations. They are consequently not representative for the GrIS (Fettweis et al., 2005; Cappelen et al., 2001), although Hanna et al. (2008) show good correspondence between DMI and Swiss Camp (west flank of GrIS) summer temperature variations since 1990. Nevertheless, we can assume that the interannual variability is less sensitive to the lack of measurements over the GrIS, the more so since the variability along the coast is a good proxy for the whole GrIS variability according to Figs. 1 and 2.

Figure 4 plots the time series of anomalies for the different datasets from 1900 to 2006. As these datasets are mainly based on the same in situ observations, the temperature time series compare very well. All the series unanimously show warm periods around 1930, 1950 and 1960 in full agreement with previous studies based on coastal DMI weather station observations (Box, 2002; Box and Cohen, 2006; Vinther et al., 2006). The rate of warming in 19201930 is the most spectacular as pointed out by Chylek et al. (2006). Finally, Greenland climate was colder around 1920 and, in the 1970s and 1980s. The temperature mini- mum (resp. maximum) seems to have occurred in 1992 after the Mont Pinatubo eruption (resp. in 1931). The warm summers of recent years $(1998,2003,2005)$, associated with large melt extent areas (Fettweis et al., 2007), seem to be less warm than these of the 1930s, as also pointed out by Hanna et al. (2007).

Concerning the precipitation time series, the agreement among them is less obvious and large disparities occur as for example with the NCEP precipitation time series in the 1950s. In addition, the interannual variability is more significant in the GHCN precipitation time series because only one or two pixels with data are available in Region 2 (Three pixels with temperature data are available in Region 1). This suggests that the precipitation variability in the GHCN time series is rather the variability measured by one or two coastal DMI weather stations. However, the series show all a small negative anomaly in the 1930s and positive in 1970s but these anomalies are less significant than the temperature anomalies. Finally, the correlation of the de-trended time series of the data sets with the MAR anomalies is better for temperature than for precipitation (see Table 2). The precipitation is more difficult to simulate and to measure (especially snowfall) which might explain these discrepancies.

Both simulated and estimated SMB anomalies through the 20th century are plotted on Fig. 5. The reference period is 1970-1999 over which the GrIS SMB simulated by MAR is $352 \pm 112 \mathrm{~km}^{3} \mathrm{yr}^{-1}$ (resp. $348 \pm 105 \mathrm{~km}^{3} \mathrm{yr}^{-1}$ for Hanna08). The generally accepted current estimate of the GrIS SMB is around $300 \mathrm{~km}^{3} \mathrm{yr}^{-1}$ which approximately balances the 
Table 4. Twenty-three AOGCMs from the IPCC AR4 (Randall et al., 2007) used in this paper. This data comes from the World Climate Research Programme's (WCRP's) Coupled Model Intercomparison Project phase 3 (CMIP3) multi-model dataset available at http://www-pcmdi.llnl.gov/.

\begin{tabular}{ll}
\hline Model ID & Sponsors, Country \\
\hline BCCR-BCM2.0 & Bjerknes Centre for Climate Research, Norway \\
CCSM3 & National Center for Atmospheric Research, USA \\
CGCM3.1(T47 \& T63) & Canadian Centre for Climate Modelling and Analysis, Canada \\
CNRM-CM3 & Météo-France/Centre National de Recherches Météorologiques, France \\
CSIRO-MK3.0 \& 3.5 & Commonwealth Scientific and Industrial Research \\
& Organisation Atmospheric Research, Australia \\
ECHAM5-MPI-OM & Max Planck Institute for Meteorology, Germany \\
ECHO-G & Meteorological Institute of the University of Bonn, Germany \\
& Meteorological Research Institute of the Korea Meteorological Administration Korea \\
FGOALS-G1.0 & National Key Laboratory of Numerical Modeling for Atmospheric Sciences \\
& and Geophysical Fluid Dynamics /Institute of Atmospheric Physics, China \\
GFDL-CM2.0 \& 2.1 & US Department of Commerce/National Oceanic and Atmospheric \\
GISS-AOM & Administration/Geophysical Fluid Dynamics Laboratory, USA \\
GISS-EH \& ER & National Aeronautics and Space Administration /Goddard Institute for Space Studies, USA \\
INM-CM3.0 & National Aeronautics and Space Administration /Goddard Institute for Space Studies, USA \\
IPSL-CM4 & Institute for Numerical Mathematics, Russia \\
MIROC3.2(hires) \& (medres) & Institut Pierre Simon Laplace, France \\
& Center for Climate System Research, National Institute for Environmental \\
MRI-CGCM2.3.2 & Studies, and Frontier Research Center for Global Change, Japan \\
PCM & Meteorological Research Institute, Japan \\
UKMO-HadCM3 \& HadGEM1 & National Center for Atmospheric Research, USA \\
& Hadley Centre for Climate Prediction and Research/Met Office, UK \\
&
\end{tabular}

glacier discharge and the basal melting rate (Reeh et al., 1999; Fettweis, 2007). Tables 2 and 3 list the ratio $a / b$, i.e. the weight of the temperature variability against the precipitation variability in the SMB variability. This ratio is obtained by using normalized (i.e. with a standard deviation of 1) de-trended temperature/precipitation anomaly time series. On average, this ratio is near $-1.0(-1.5,-0.75)$. The details of the uncertainty of the ratio $a / b$ is explained in the legend of Table 2. Therefore, the thermal factors influence the SMB sensitivity as much as precipitation changes.

The set of SMB estimates in Fig. 5 agree to give positive anomalies around 1920 and in the 1970s and 1980s. The maximum, confirmed by all data sets, takes place at the beginning of the 1970s with a SMB anomaly near $+200 \mathrm{~km}^{3} \mathrm{yr}^{-1}$ due to a combination of cold summers and wet years. Over the period 1930-1960 and since the end of 1990s, the estimated SMB is below the 1970-1999 average. The absolute minimum occurred around 1930 with a SMB anomaly near $-300 \mathrm{~km}^{3} \mathrm{yr}^{-1}$. Secondary (minor) SMB minima appear to have occurred in 1950 and 1960, equalling the surface mass loss rates of the last few years (1998, 2003, 2006), although these minima are not confirmed in all data sets. However (Chylek et al., 2007) found also a maximum melt area at the beginning of the 1930s followed by minor maxima in 1950 and 1960. The minimum SMB rates around 1930 are due to exceptionally warm summers combined with dry years inducing SMB rates lower than those currently observed, although the effect of human-induced global warming was not perceptible at that time. Around 1950 and 1960, the low SMB rates are mainly explained by positive temper- ature anomalies. After the 1990s, the GrIS SMB decreases slowly to reach the negative anomalies of the last few years, although the summers of the 2000s were not exceptional compared to $70 \mathrm{yr}$ ago (Chylek et al., 2006).

Finally, the interannual SMB variability was higher in 1960-1990 than in the 1930s and 2000s. During 1960-1990, negative SMB anomalies were mainly succeeded by positive anomalies. By contrast, in the 1930s and 2000s, there is a succession of negative SMB anomalies inducing an acceleration of the melt due to the albedo feedback. A high melt-rate year decreases the snow pack albedo for the next year if the winter accumulation is not enough to compensate the melt during the next summer (Fettweis, 2007).

\section{Change in the future}

In the following section, we assume that the hypotheses made before are still valid in the near future. In that case, AOGCM simulations (Randall et al., 2007) performed for the 4th assessment report of the IPCC can be used to project the GrIS SMB anomalies for the 21 st century. The projected temperature/precipitation anomalies (plotted in Fig. 6) are based on model outputs from the "Climate of the Twentieth Century Experiment" (20C3M) and from the scenario SRES (Special Report on Emission Scenarios) A1B described in Nakicenovic et al. (2000). The A1B scenario corresponds to a continuous increase of the atmospheric $\mathrm{CO}_{2}$ concentration during the 21 st century to a level of $720 \mathrm{ppm}$ by 2100 . The A1B 

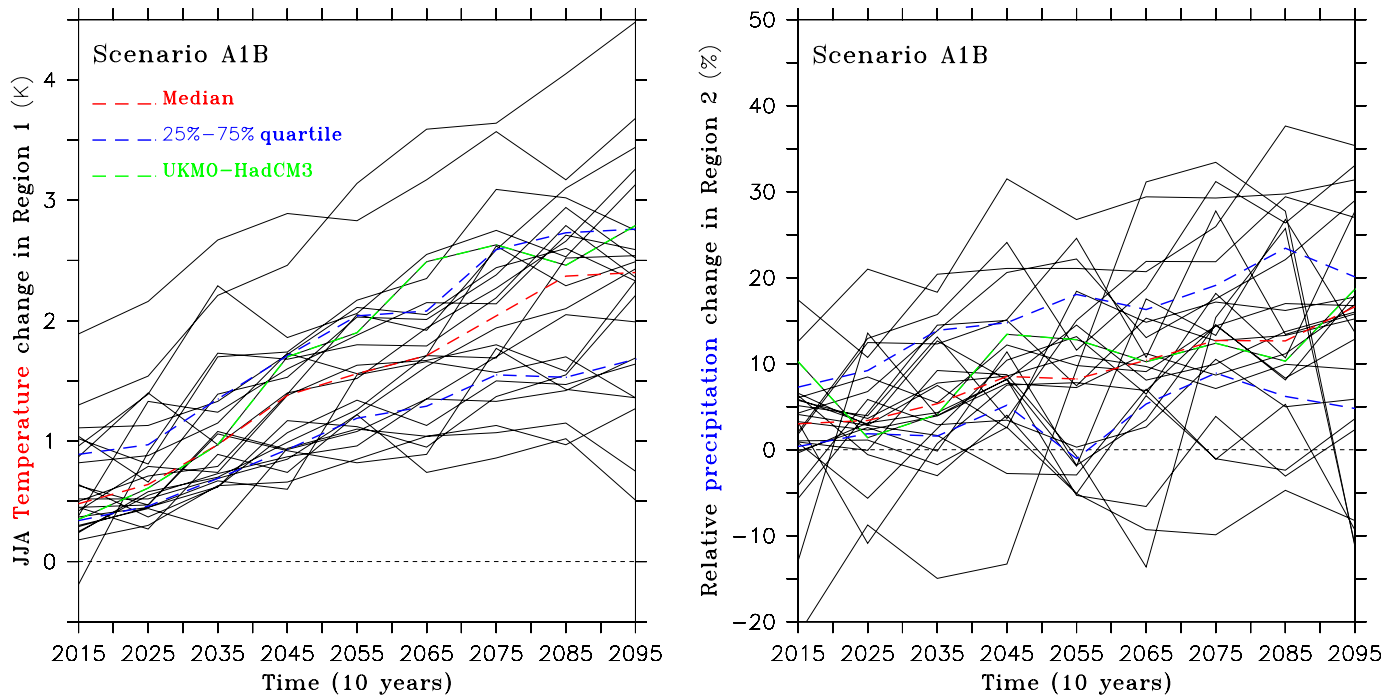

Fig. 6. Time series of temperature (resp. precipitation) anomalies projected by AOGCMs listed in Table 4. The anomalies are decadal means, computed on Region 1 and 2 described previously and refer to the period 1970-1999. The anomalies are based on model outputs from the "Climate of the Twentieth Century Experiment" (20C3M) and from the scenario SRES A1B. Finally, the median (50\%), the 25\% and 75\% quartile values among the 24 models and the UKMO-HadCM3 time series are plotted in red, blue and green, respectively.

scenario was chosen because it is a mid-range scenario and all the IPCC AR4 AOGCMs have outputs for this scenario.

We deduce the projected SMB changes in the future from the IPCC AR4 experiments (Randall et al., 2007) via the following algorithm:

1. The time series of the JJA temperature $\left(T_{i}\right)$ taken in Region 1 and the annual precipitation $\left(P_{i}\right)$ taken in Region 2 from the $20 \mathrm{C} 3 \mathrm{M}$ experiment are de-trended, centred i.e.

$\bar{T}=\frac{1}{30} \sum_{i=1970}^{1999} T_{i}=\bar{P}=0$

and normalized (i.e. with a standard deviation of 1):

$\sqrt{\frac{1}{29} \sum_{i=1970}^{1999} T_{i}^{2}}=\sqrt{\frac{1}{29} \sum_{i=1970}^{1999} P_{i}^{2}}=1$

over 1970-1999. The normalisation of the $T_{i}$ and $P_{i}$ time series enables to homogenise the AOGCMs results over 1970-1999.

2. The MAR and Hanna08 results show a standard deviation of the GrIS SMB time series around $100 \mathrm{~km}^{3} \mathrm{yr}^{-1}$ over the period 1970-1999. Therefore, if $k=a / b$, the standard deviation of the SMB estimated by the temperature and precipitation time series from the $20 \mathrm{C} 3 \mathrm{M}$ experiment is fixed to be $100 \mathrm{~km}^{3} \mathrm{yr}^{-1}$, i.e.

$\sqrt{\frac{1}{29} \sum_{i=1970}^{1999}\left(a T_{i}+b P_{i}\right)^{2}}$

$$
\begin{aligned}
& =a \sqrt{\frac{1}{29} \sum_{i=1970}^{1999}\left(T_{i}+\frac{1}{k} P_{i}\right)^{2}} \text { for } k=\frac{a}{b} \\
& =100 \mathrm{~km}^{3} \mathrm{yr}^{-1}
\end{aligned}
$$

which enables the computation of $a$ and $b$ if the parameter $k$ is known. Previous results listed in Tables 2 and 3 show a parameter $k$ around $-1.0(-1.5,-0.75)$. Here, we will compute $a$ and $b$ for $k$ fixed at -1 .

3. For each decade between the 2010s and the 2090s, the mean projected summer temperature (resp. annual precipitation) in Region 1 (resp. Region 2) is retrieved from the SRESA1B scenario. Afterwards, the mean 1970 1999 temperature (resp. precipitation) from the 20C3M experiment is subtracted from the projected temperature (resp. precipitation) to compute anomalies which we divide by the normalisation factor used in Eq. (3) to give this equation:

$$
\begin{aligned}
& \Delta \mathrm{SMB}=a \frac{\overline{T_{S R E S A 1 B}}-\overline{T_{20 C 3 M}}}{\operatorname{stdev}\left(T_{20 C 3 M}\right)} \\
& +b \frac{\overline{P_{S R E S A 1 B}}-\overline{P_{20 C 3 M}}}{\operatorname{stdev}\left(P_{20 C 3 M}\right)}
\end{aligned}
$$

By using parameters $a$ and $b$ computed in Eq. (4), we can then estimate the projected SMB anomaly for each decade based on a fixed value of $k$. 
Table 5. Future projections for the 21 st century from the ensemble mean of the AOGCMs simulations performed for the IPCC AR4. The two last lines use simulations made for the SRESA2 experiments against SRESA1B for the other ones. The table shows the median (50\%), and $25 \%$ and $75 \%$ quartile values among the 24 models.

\begin{tabular}{lcccccc}
\hline Decade & $\Delta T$ & $\frac{\Delta P}{\bar{P}}$ & $\begin{array}{c}\Delta \text { SMB for } \frac{a}{b}=-0.75 \\
\text { in km } 3 / \mathrm{yr}\end{array}$ & $\begin{array}{c}\Delta \text { SMB for } \frac{a}{b}=-1 \\
\text { in km} / \mathrm{yr}\end{array}$ & $\begin{array}{c}\Delta \text { SMB for } \frac{a}{b}=-1 \\
\text { in mm/yr sea level-eq. }\end{array}$ & $\begin{array}{c}\Delta \text { SMB for } \frac{a}{b}=-1.5 \\
\text { in } \mathrm{km}^{3} / \mathrm{yr}\end{array}$ \\
\hline $2010-2019$ & $+0.5(+0.3,+0.9)$ & $+3(+0,+7)$ & $-45(-77,-15)$ & $-57(-95,-35)$ & $+0.16(+0.1,+0.26)$ & $-67(-114,-45)$ \\
$2020-2029$ & $+0.6(+0.5,+1.0)$ & $+3(+2,+9)$ & $-57(-73,-39)$ & $-75(-101,-57)$ & $+0.21(+0.16,+0.28)$ & $-91(-119,-71)$ \\
$2030-2039$ & $+1.0(+0.7,+1.3)$ & $+5(+2,+14)$ & $-78(-107,-41)$ & $-111(-137,-75)$ & $+0.31(+0.21,+0.38)$ & $-137(-176,-91)$ \\
$2040-2049$ & $+1.4(+0.9,+1.7)$ & $+9(+5,+15)$ & $-89(-108,-53)$ & $-127(-166,-114)$ & $+0.35(+0.31,+0.46)$ & $-172(-224,-138)$ \\
$2050-2059$ & $+1.6(+1.2,+2.0)$ & $+8(-1,+18)$ & $-117(-151,-77)$ & $-150(-199,-134)$ & $+0.42(+0.37,+0.55)$ & $-200(-243,-172)$ \\
$2060-2069$ & $+1.7(+1.3,+2.1)$ & $+10(+5,+16)$ & $-125(-159,-84)$ & $-179(-215,-139)$ & $+0.5(+0.38,+0.59)$ & $-224(-277,-185)$ \\
$2070-2079$ & $+2.0(+1.5,+2.6)$ & $+13(+9,+19)$ & $-130(-158,-110)$ & $-203(-241,-162)$ & $+0.56(+0.45,+0.67)$ & $-264(-323,-208)$ \\
$2080-2089$ & $+2.4(+1.5,+2.7)$ & $+13(+6,+23)$ & $-161(-202,-104)$ & $-239(-260,-187)$ & $+0.66(+0.52,+0.72)$ & $-303(-335,-238)$ \\
$2090-2099$ & $+2.4(+1.7,+2.8)$ & $+17(+5,+20)$ & $-167(-210,-111)$ & $-242(-297,-185)$ & $+0.67(+0.51,+0.82)$ & $-324(-371,-249)$ \\
\hline $2080-2089$ & $+2.6(+2.3,+3.1)$ & $+12(+9,+21)$ & $-182(-235,-140)$ & $-258(-326,-211)$ & $+0.71(+0.59,+0.90)$ & $-345(-421,-279)$ \\
$2090-2099$ & $+3.0(+2.0,+3.5)$ & $+17(+11,+24)$ & $-184(-245,-157)$ & $-291(-351,-236)$ & $+0.81(+0.65,+0.97)$ & $-371(-427,-308)$ \\
\hline
\end{tabular}
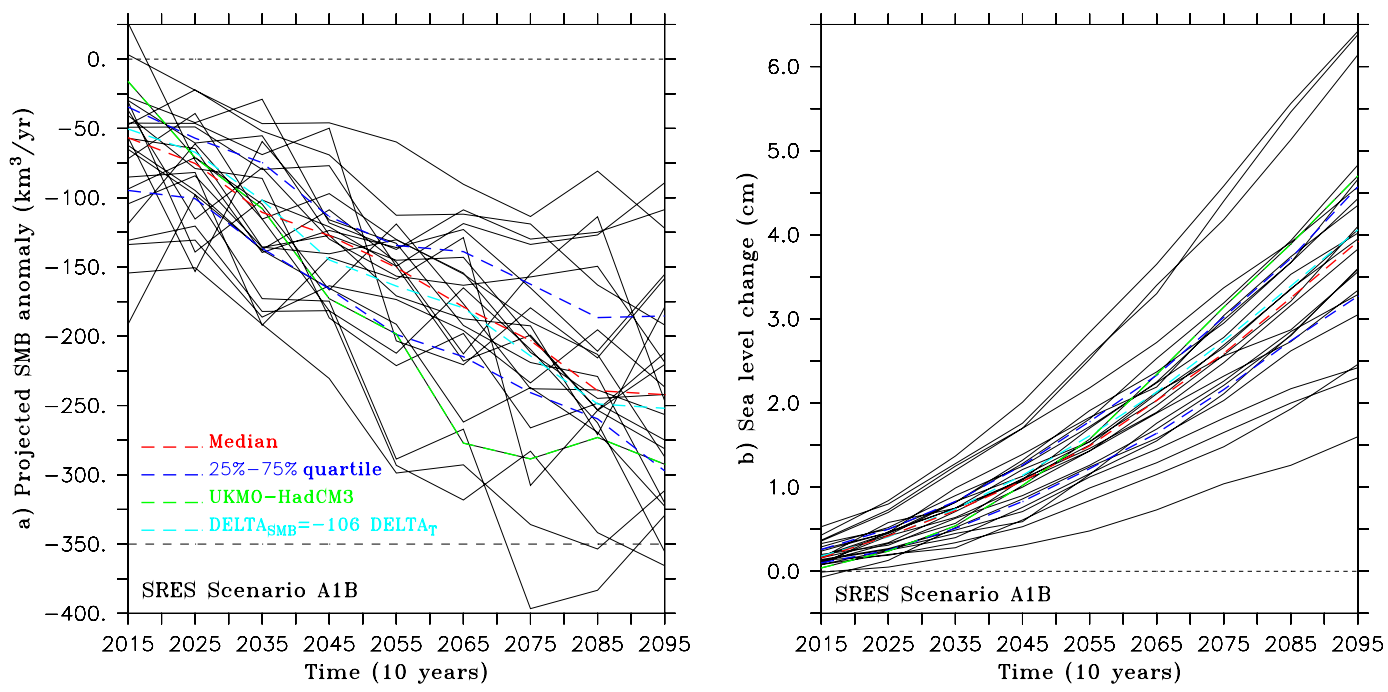

Fig. 7. (a) Time series of SMB anomalies projected by AOGCMs listed in Table 4 for $a / b=-1$. The anomalies are decadal means and refer to 1970-1999 where the mean SMB rate is estimated to be $\sim 350 \mathrm{~km}^{3} / \mathrm{yr}$. The anomalies are based on model outputs from the "Climate of the Twentieth Century Experiment" (20C3M) and from the scenario SRES A1B. Finally, the median (50\%), the $25 \%$ and $75 \%$ quartile values among the 24 models, Eq. (7) and the UKMO-HadCM3 time series are plotted in red, dark blue, light blue and green, respectively. (b) The same as a) but for the projected GrIS SMB changes expressed in equivalent sea-level rise (in $\mathrm{cm}$ ). The computation was made by using an area of a world ocean area of 361 million $\mathrm{km}^{2}$. 


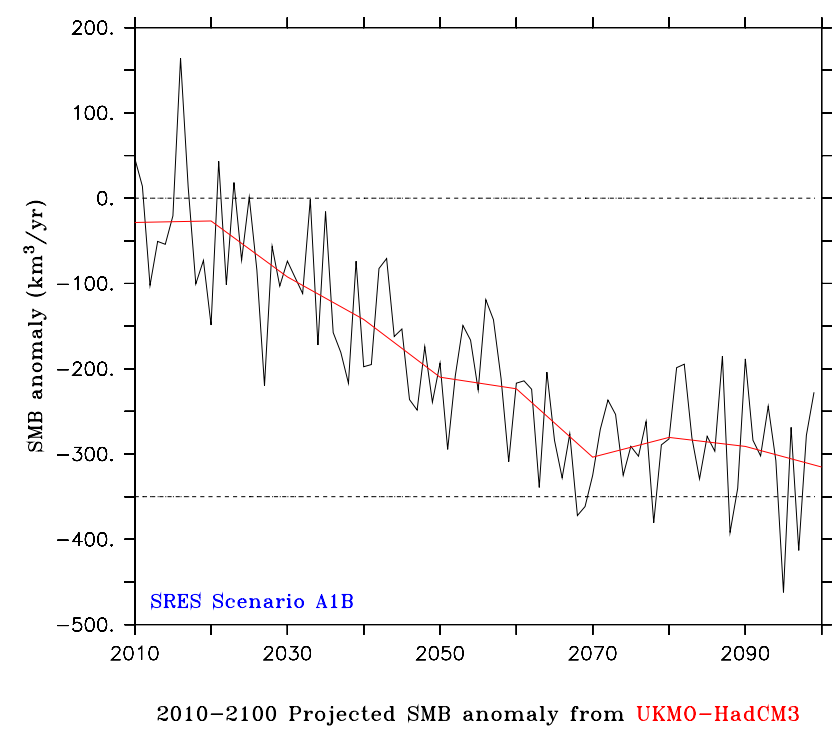

Fig. 8. The 2010-2100 projected SMB anomaly using temperature/precipitation anomaly simulated by UKMO-HadCM3 for $k=-1$. The temperature/precipitation projections from UKMOHadCM3 are near the ensemble mean and its SMB anomaly projections are at the negative end compared with other models. The 10 -yr running mean is shown in red.

For validation purposes, this algorithm was first applied to the ECMWF, NCEP and GHCN time series (1970-1999) by taking a value of -1 for the parameter $k$. The resulting estimated SMB time series agree well with those simulated by Hanna08. The correlation coefficient is respectively $0.96,0.97$ and 0.86 for a RMSE equals to $32.6,30.7$ and $55.5 \mathrm{~km}^{3} \mathrm{yr}^{-1}$. These results should be compared with those listed in Table 3. An alternative to this algorithm (using a fixed value of $k$ ) is to directly infer the parameter $a$ and $b$ from the regressions listed in Table 3 (in average, $a \simeq-60 \pm 10$ and $b \simeq+60 \pm 10$ ). However, in this case, the RMSE with the SMB time series simulated by Hanna08 is higher.

Figure 6 plots the decadal mean of the JJA temperature and relative precipitation changes for all models listed in Table 4 . While the interdecadal variability is very high (particularly for precipitation) and some models are in total disagreement with the others, the models are unanimous in projecting a JJA temperature increase of $\sim 2.4^{\circ} \mathrm{C}$ through the 21 st century. Changes in precipitation are more model-dependent than temperature although the multimodel average gives a small increase of precipitation during the 21 st century. The relative precipitation change could be estimated to be $\sim 5 \%$ $\mathrm{K}^{-1}$ in connection with the temperature increase, as found by Gregory and Huybrechts (2006). Table 5 summarises the changes projected for the 21 st century. These results are in agreement with the projections of the IPCC AR4 (Christensen et al., 2007) for 2090-2099 (compared with 1980$1999)$ over a region covering the Greenland $\left(103^{\circ} \mathrm{W}-10^{\circ} \mathrm{W}\right.$ and $50^{\circ} \mathrm{N}-85^{\circ} \mathrm{N}$.). Their projections are $+2.8 \mathrm{~K}(+2.1,+3.7)$ for the JJA temperature and $+15 \%(+12,+20)$ for the annual relative precipitation. Their values are the median $(50 \%)$, and $25 \%$ and $75 \%$ quartile values among 21 AOGCMs.

The ensemble mean of the 24 models used in the 20C3M experiment (see Table 4) gives a mean surface JJA temperature (resp. precipitation) of $-1.2 \pm 2.7^{\circ} \mathrm{C}$ (resp. $530 \pm 157 \mathrm{~mm}$ ) and a trend of $+0.02 \mathrm{~K}^{\circ} \mathrm{yr}^{-1}$ (resp. no significant precipitation change) in Region 1 (resp. Region 2) over the reference period 1979-1999. These results are in agreement with observations during 1970-1999, suggesting that the multimodel average is a reliable estimate for the current climate. In a first approach, we decided to use only results of the ensemble mean for future projections rather than those from a single model. Sophisticated weighting of the various models should be investigated in the future.

The SMB anomaly projection for $k=a / b=-1$ as well as the cumulated sea level rises equivalent are shown in Fig. 7 and listed in Table 5. The lower SMB anomaly in the 20th century seems to have occurred in 1931 with $-300 \mathrm{~km}^{3} \mathrm{yr}^{-1}$. This record surface mass loss rate is likely to become common at the end of the 21st century. The summer will probably be much warmer than previously observed during the 20th century, but a predicted increase of precipitation will most likely partly offset the SMB decrease associated with warming. With the SRESA2 experiment, the projected negative SMB anomalies are higher. The sea level rise coming from the GrIS SMB change should reach $4 \pm 0.5 \mathrm{~cm}$ in 2100 , which is in full agreement with Huybrechts et al. (2004), Oerlemans et al. (2005) and Meehl et al. (2007). The computation was made by using an area of a world ocean area of 361 million $\mathrm{km}^{2}$. Finally, Table 5 and Fig. 7 show that a warming threshold higher than $2.5 \mathrm{~K}$ is required for a zero surface mass balance (i.e. a SMB anomaly reaching $-350 \mathrm{~km}^{3} / \mathrm{yr}$ in our case), as concluded by Gregory and Huybrechts (2006).

However, it should be noted that the MAR model simulates for 2003 and 2006 negative SMB anomalies equivalent to those projected by the AOGCMs on average for the end of the 21 st century. These recent SMB rates are the result of low precipitation and very high temperatures (an anomaly of about $2^{\circ} \mathrm{K}$ occurred in 2003), suggesting that some AOGCMs could underestimate changes resulting from the global warming over the GrIS. These projections are decadal means suggesting that some SMB anomalies could be much lower for individual years (see Fig. 8) owing to the high observed interannual variability in the SMB (see Fig. 3). In addition to the uncertainties linked to the models/scenario and the value of $k$, these projections do not take into account changes in ice dynamics and surface topography as described in Gregory and Huybrechts (2006). An albedo decrease as well as a decrease of the surface height due to successive annual negative GrIS mass rates induces an acceleration of the melt. In addition to these surface changes, there may be changes in glacier discharge (e.g. from melt-induced outlet 
glacier acceleration as observed by Zwally et al., 2002) and in basal melting currently estimated to be $\sim 300 \mathrm{~km}^{3} \mathrm{yr}^{-1}$ by Reeh et al. (1999).

According to Eq. (5) and if we assume that the relative precipitation change is $5 \% \mathrm{~K}^{-1}$ in connection with the temperature increase (Gregory and Huybrechts, 2006), the ensemble mean of the IPCC AR4 models shows that the projected SMB changes in a near future could be approximated by

$$
\begin{aligned}
\Delta S M B & =a \frac{\Delta T}{\operatorname{stdev}\left(T_{20 C 3 M}\right)}+b \frac{\Delta P}{\operatorname{stdev}\left(P_{20 C 3 M}\right)} \\
& =\sim(-106 \pm 26) \Delta T
\end{aligned}
$$

for $k=a / b=-1.0(-1.5,-0.75)$. The striking fit between the Eq. (7) plotted in Fig. 7 in light blue and the ensemble mean in red motived us to use Eq. (7) with the IPCC AR4 projections. Following the used SRES scenario, the best estimates from the IPCC AR4 project a global average surface warming varying between 1.8 and $4 \mathrm{~K}$ in 2100 (IPCC, 2007). If we assume that the summer GrIS temperature increase will be equivalent to the global warming, Eq. (7) then estimates $\triangle S M B$ to vary between $-190 \pm 47$ and $-424 \pm 104 \mathrm{~km}^{3} \mathrm{yr}^{-1}$ in 2100. In particular for the mid-range SRES scenario A1B, the IPCC AR4 (IPCC, 2007) projects a global temperature increase of $+2.8 \mathrm{~K}(+1.7,+4.4)$ inducing a SMB change of $-297 \pm 73(-180 \pm 44,-466 \pm 114) \mathrm{km}^{3} \mathrm{yr}^{-1}$ in 2100 . Therefore, it is very likely that the GrIS SMB should be null or even negative in 2100 .

However, ten thousand years would be needed to melt completely the GrIS if the SMB stabilizes near $0 \mathrm{~km}^{3} \mathrm{yr}^{-1}$. Indeed, the total volume of the GrIS is $2.93 \times 10^{6} \mathrm{~km}^{3}$ (Bamber et al., 2001) and the current mass loss from glacier discharge and basal melting is estimated to be $\sim 300 \mathrm{~km}^{3} \mathrm{yr}^{-1}$ (Reeh et al., 1999), while some recent observations from the Gravity Recovery and Climate Experiment (GRACE) suggest that dynamic mass losses should be much higher within the last five years (Chen et al., 2006; Luthcke et al., 2006; Thomas et al., 2006, Velicogna and Wahr, 2006). However, this simple calculation does not take into account the positive feedbacks from albedo and elevation changes (Ridley et al., 2005) or changes in ice dynamics nor the fact that in a warmer climate the ice sheet will retreat from the coast so that less calving can take place.

\section{Discussion and conclusion}

Simulations made with MAR (Fettweis, 2007) and by Hanna et al. (2008) reveal a very high correlation between the interannual variability of the modelled SMB and the variability of both temperature and precipitation GrIS anomalies. We have derived a multiple-regression relation that has been used with climatological time series to empirically estimate the GrIS SMB since 1900. The SMB changes projected for the end of the 21st century have been derived using the set of experiments conducted for the IPCC AR4 (Randall et al., 2007).
The results show that the GrIS surface mass loss in the 1930s is likely to have been more significant than currently due to a combination of very warm and dry years. It is also noted from our results that a mere ten years would be enough to pass from a GrIS growth state to a significant mass-loss state. Therefore, the SMB changes that are currently occurring, and which are linked to global warming (Fettweis, 2007; Hanna et al., 2008) are not exceptional in the GrIS history. For the near future, the IPCC AR4 models project SMB rates similar to those of the 1930s (i.e. a zero or even negative SMB rate) for the end of the 21st century. That transforms to about 4-5 cm of sea-level rise for the end of this century under SRES scenario A1B. If these rates are confirmed and no significant changes occur in iceberg calving and basal melting, then these rates are not large enough to significantly change the freshwater flux into the Atlantic Ocean.

However, large uncertainties remain indeed in these estimates due to models/scenarios used as well as parameters and hypotheses made in the algorithm to estimate the GrIS SMB anomaly. That is why further investigations are needed. High-resolution simulations made with the MAR model (which explicitly simulates the SMB by incorporating the surface feedbacks) forced at its boundaries by the IPCC AR4 models outputs should yield more comprehensive and realistic results although this requires a lot of computing time. Moreover, both 2003 and 2006 negative SMB anomalies simulated by MAR resulting from a combination of low precipitation and very high temperatures are equivalent to those projected by the AOGCMs on average for the end of the 21 st century. This suggests that some AOGCMs could underestimate changes over the GrIS from the global warming.

Acknowledgements. We acknowledge the modelling groups, the Program for Climate Model Diagnosis and Intercomparison (PCMDI) and the WCRP's Working Group on Coupled Modelling (WGCM) for their roles in making available the WCRP CMIP3 multi-model dataset. Support of this dataset is provided by the Office of Science, US Department of Energy. We thank also the British Atmospheric Data Centre and European Centre for Medium-Range Weather Forecasts (ECMWF) for ECMWF reanalysis and operational analysis data (used for driving the MAR model and the Hanna et al. (2008) SMB model). Finally, the authors want to thank Wouter Lefebvre for his extremely valuable comments.

Edited by: D. Hall 


\section{References}

Bamber, J. L., Layberry, R. L., and Gogineni, S. P.: A new ice thickness and bed data set for the Greenland ice sheet: part I, Measurement, data reduction, and errors, J. Geophys. Res., 106, 33 773-33 780, 2001.

Box, J. E.: Survey of Greenland instrumental temperature records: 1873-2001, Int. J. Climatol., 22, 1829-1847, 2002.

Box, J. E., Bromwich, D. H., and Bai, L.-S.: Greenland ice sheet surface mass balance for 1991-2000: application of Polar MM5 mesoscale model and in-situ data, J. Geophys. Res., 109(D16), D16105, doi:10.1029/2003JD004451, 2004.

Box, J. E. and Cohen, A. E.: Upper-air temperatures around Greenland: 1964-2005, Geophys. Res. Lett., 33, L12706, doi:10.1029/2006GL025723, 2006.

Box, J. E., Bromwich, D. H., Veenhuis, B. A., Bai, L.-S., Stroeve, J. C., Rogers, J. C., Steffen, K., Haran, T., and Wang, S.-H.: Greenland ice sheet surface mass balance variability (1988-2004) from calibrated Polar MM5 output, J. Climate, 19(12), 2783-2800, 2006.

Cappelen, J., Jorgensen, B. V., Laursen, E. V., Stannius, L. S., and Thomsen, R. S.: The observed climate of Greenland, 1958-99 - with climatological standard normals, 1961-1990, Tech. Rep. 00-18, 152 pp., Danish Meteorological Institute, Copenhagen, 2001.

Chen J. L., Wilson, C. R., and Tapley, B. D.: Satellite Gravity Measurements Confirm Accelerated Melting of Greenland Ice Sheet, Science, 313, 1958-1960, doi:10.1126/science.1129007, 2006.

Chylek, P., Dubey, M. K., and Lesins, G.: Greenland warming of 1920-1930 and 1995-2005, Geophys. Res. Lett., 33, L11707, doi:10.1029/2006GL026510, 2006.

Chylek, P., McCabe, M., Dubey, M. K., and Dozier, J.: Remote sensing of Greenland ice sheet using multispectral nearinfrared and visible radiances, J. Geophys. Res., 112, D24S20, doi:10.1029/2007JD008742, 2007.

Christensen, J. H., Hewitson, B., Busuioc, A., Chen, A., Gao, X., Held, I., Jones, R., Kolli, R. K., Kwon, W.-T., Laprise, R., Magana Rueda, V., Mearns, L., Menendez, C. G., Risnen, J., Rinke, A., Sarr, A., and Whetton, P.: Regional Climate Projections, in: Climate Change 2007: The Physical Science Basis. Contribution of Working Group I to the Fourth Assessment Report of the Intergovernmental Panel on Climate Change, edited by: Solomon, S., Qin, D., Manning, M., Chen, Z., Marquis, M., Averyt, K. B., Tignor, M., and Miller, H. L., Cambridge University Press, Cambridge, United Kingdom and New York, NY, USA, 2007.

Christy, J. R., Spencer, R. W., and Braswell, W. D.: MSU Tropospheric temperatures: Data set construction and radiosonde comparisons, J. Atmos. Ocean. Tech., 17, 1153-1170, 2000.

Cuffey, K. M. and Marshall, S. J.: Substantial contribution to sea level rise during the last interglacial from the Greenland ice sheet, Nature, 404, 591-594, 2000.

Dai, A., Fung, I. Y., and Del Genio, A. D.: Surface observed global land precipitation variations during 1900-1988, J. Climate, 10, 2943-2962, 1997.

Fettweis, X., Gallée, H., Lefebre, L., and van Ypersele, J.-P.: Greenland surface mass balance simulated by a regional climate model and comparison with satellite derived data in 1990-1991, Clim. Dynam., 24, 623-640, doi:10.1007/s00382-005-0010-y, 2005.

Fettweis, X., van Ypersele, J.-P., Gallée, H., Lefebre, F., and Lefeb- vre, W.: The 1979-2005 Greenland ice sheet melt extent from passive microwave data using an improved version of the melt retrieval XPGR algorithm, Geophys. Res. Lett., 34, L05502, doi:10.1029/2006GL028787, 2007.

Fettweis, X.: Reconstruction of the 1979-2006 Greenland ice sheet surface mass balance using the regional climate model MAR, The Cryosphere, 1, 21-40, 2007.

Gregory, J., Dixon, K., Stouffer, R. J., Weaver, A., Driesschaert, E., Eby, M., Fichefet, T., Hasumi, H., Hu, A., Jungclaus, J., Kamenkovich, I., Levermann, A., Montoya, M., Murakami, S., Nawrath, S., Oka, A., Solokov, A., and Thorpe, R.: A model intercomparison of changes in the Atlantic thermohaline circulation in response to increasing atmospheric concentration, Geophys. Res. Lett., 32, L12703, doi:10.1029/2005GL023209, 2005.

Gregory, J. and Huybrechts, P.: Ice-sheet contributions to future sea-level change, Philos. T. R. Soc. A, 364, 1709-1731, 2006.

Hanna, E., Box, J., and Huybrechts, P.: Greenland Ice Sheet mass balance, Arctic Report Card 2007, update to State of Arctic Report 2006, NOAA, available at http://www.arctic.noaa.gov/ reportcard/, 2007.

Hanna, E., Huybrechts, P., Steffen, K. , Cappelen, J., Huff, R., Shuman, C., Irvine-Fynn, T., Wise, S., and Griffiths, M.: Increased runoff from melt from the Greenland Ice Sheet: a response to global warming, J. Climate, 21, 331-341, 2008.

Huybrechts, P., Gregory, J., Janssens, I., and Wild, M.: Modelling Antarctic and Greenland volume changes during the 20th and 21st centuries forced by GCM time slice integrations, Global Planet. Change, 42, 83-105, doi:10.1016/j.gloplacha.2003.11.011, 2004.

IPCC, 2007: in: Climate Change 2007: The Physical Science Basis. Contribution of Working Group I to the Fourth Assessment Report of the Intergovernmental Panel on Climate Change, edited by: Solomon, S., Qin, D., Manning, M., Chen, Z., Marquis, M., Averyt, K. B., Tignor, M., and Miller, H. L., Cambridge University Press, Cambridge, United Kingdom and New York, NY, USA, 2007.

Kalnay, E., Kanamitsu, M., Kistler, R., Collins, W., Deaven, D., Gandin, L., Iredell, M., Saha, S., White, G., Woollen, J., Zhu, Y., Leetmaa, A., Reynolds, B., Chelliah, M., Ebisuzaki, W., Higgins, W., Janowiak, J., Mo, K., Ropelewski, C., Wang, J., Jenne, R., and Joseph, D.: The NCEP/NCAR 40-Year Reanalysis Project, B. Am. Meteorol. Soc., 77, 437-471, 1996.

Luthcke, S. B., Zwally, H. J., Abdalati, W., Rowlands, D. D., Ray, R. D., Nerem, R. S., Lemoine, F. G., McCarthy, J. J., and Chinn, D. S.: Recent Greenland Ice Mass Loss by Drainage System from Satellite Gravity Observations, Science, 314(5803), 1286, doi:10.1126/science.1130776, 2006.

Meehl, G. A., Stocker, T. F., Collins, W. D., Friedlingstein, P., Gaye, A. T., Gregory, J. M., Kitoh, A., Knutti, R., Murphy, J. M., Noda, A., Raper, S. C. B., Watterson, I. G., Weaver, A. J., and Zhao, Z.-C.: Global Climate Projections, in: Climate Change 2007: The Physical Science Basis. Contribution of Working Group I to the Fourth Assessment Report of the Intergovernmental Panel on Climate Change, edited by: Solomon, S., Qin, D., Manning, M., Chen, Z., Marquis, M., Averyt, K. B., Tignor, M., and Miller, H. L., Cambridge University Press, Cambridge, United Kingdom and New York, NY, USA, 2007.

Mitchell, T. D. and Jones, P. D.: An improved method of constructing a database of monthly climate observations and associated 
high-resolution grids, Int. J. Climatol., 25, 693-712, 2005.

Nakicenovic, N., Alcamo, J., Davis, G., et al.: Special Report on Emissions Scenarios: A Special Report of Working Group III of the Intergovernmental Panel on Climate Change, Cambridge University Press, Cambridge, UK, 599 pp., available online at: http://www.grida.no/climate/ipcc/emission, 2000.

Peterson, T. C. and Vose, R. S.: An overview of the Global Historical Climatology Network temperature database, B. Am. Meteorol. Soc., 78(12), 2837-2849, 1997.

Oerlemans, J., Bassford, R. P., Chapman, W., Dowdeswell, J. A., Glazovsky, A. F., Hagen, J. O., Melvold, K., de Wildt, M. R. and van de Wal, R. S. W.: Estimating the contribution from Arctic glaciers to sea-level change in the next hundred years, Ann. Glaciol, 42, 230-236, 2005.

Rahmstorf, S., Crucifix, M., Ganopolski, A., Goosse, H., Kamenkovich, I., Knutti, R., Lohmann, G., Marsh, R., Mysak, L. A., Wang, Z., and Weaver, A. J.: Thermohaline circulation hysteresis: A model intercomparison, Geophys. Res. Lett., 32(23), L23605, doi:10.1029/2005GL023655, 2005.

Randall, D. A., Wood, R. A., Bony, S., Colman, R., Fichefet, T., Fyfe, J., Kattsov, V., Pitman, A., Shukla, J., Srinivasan, J., Stouffer, R. J., Sumi, A., and Taylor, K. E.: Climate Models and Their Evaluation, in: Climate Change 2007: The Physical Science Basis. Contribution of Working Group I to the Fourth Assessment Report of the Intergovernmental Panel on Climate Change, edited by: Solomon, S., Qin, D., Manning, M., Chen, Z., Marquis, M., Averyt, K. B., Tignor, M., and Miller, H. L., Cambridge University Press, Cambridge, United Kingdom and New York, NY, USA, 2007.

Reeh, N., Mayer, C., Miller, H., Thomson, H. H., and Weidick, A.: Present and past climate control on fjord glaciations in Greenland: Implications for IRD-deposition in the sea, Geophys. Res. Lett., 26, 1039-1042, 1999.

Ridley, J., Huybrechts, P., Gregory, J. M., and Lowe, J.: Elimination of the Greenland ice sheet in a high- $\mathrm{CO}_{2}$ climate, J. Climate, 18(17), 3409-3427, 2005.
Rignot, E. and Kanagaratnam, P.: Changes in the Velocity Structure of the Greenland Ice Sheet, Science, 311, 986-990, doi: 10.1126/science.112138, 2006.

Swingedouw, D., Braconnot, P., and Marti, O.: Sensitivity of the Atlantic Meridional Overturning Circulation to the melting from northern glaciers in climate change experiments, Geophys. Res. Lett., 33, L07711, doi:10.1029/2006GL025765, 2006.

Thomas, R., Frederick, E., Krabill, W., Manizade, S., and Martin, C.: Progressive increase in ice loss from Greenland, Geophys Res. Lett., 33, L10503, doi:10.1029/2006GL026075, 2006.

Uppala, S. M., Kallberg, P. W., Simmons, A. J., Andrae, U., da Costa Bechtold, V., Fiorino, M., Gibson, J. K., Haseler, J., Hernandez, A., Kelly, G. A., Li, X., Onogi, K., Saarinen, S., Sokka N., Allan, R. P., Andersson, E., Arpe, K., Balmaseda, M. A., Beljaars, A. C. M., van de Berg, L., Bidlot, J., Bormann, N., Caires, S., Chevallier, F., Dethof, A., Dragosavac, M., Fisher, M., Fuentes, M., Hagemann, S., Holm, E., Hoskins, B., Isaksen, L., Janssen, P. A. E. M., Jenne, R., McNally, A. P., Mahfouf, J.F., Morcrette, J.-J., Rayner, N. A., Saunders, R. W., Simon, P., Sterl, A., Trenberth, K. E., Untch, A.,Vasiljevic, D., Viterbo, P., and Woollen, J.: The ECMWF re-analysis, Q. J. Roy. Meteor. Soc., 131, 2961-3012, doi:10.1256/qj.04.176, 2005.

Velicogna, I. and J. Wahr: Measurements of Time-Variable Gravity Show Mass Loss in Antarctica, Science, 311(5768), 1754-1756, 2006.

Vinther, B. M., Andersen, K. K., Jones, P. D., Briffa, K. R., and Cappelen, J.: Extending Greenland temperature records into the late eighteenth century, J. Geophys. Res., 111, D11105, doi:10.1029/2005JD006810, 2006.

Zwally, J. H., Abdalati, W., Herring, T., Larson, K., Saba, J., and Steffen, K.: Surface Melt-Induced Acceleration of Greenland Ice-Sheet Flow, Science, 297, 218-222, 2002. 